Erratum

\title{
Erratum to the Introduction to the Special Issue on Olduvai Gorge "Paleoecology and hominin behavior during Bed I at Olduvai Gorge (Tanzania)" [Quaternary Research 74 (2010) 1-3]
}

\author{
M. Domínguez-Rodrigo a,b,*, H.T. Bunnc, A. Mabulla ${ }^{\mathrm{d}}$, E. Baquedano ${ }^{\mathrm{a}, \mathrm{e}}$, T.R. Pickering,g \\ a IDEA (Instituto de Evolución en África), Museo de los Orígenes, Plaza de San Andrés 2, 28005 Madrid, Spain \\ ${ }^{\mathrm{b}}$ Department of Prehistory, Complutense University, Prof. Aranguren s/n, 28040 Madrid, Spain \\ c Department of Anthropology, University of Wisconsin-Madison, 1180 Observatory Drive, Madison, Wisconsin, 53706, USA \\ d Archaeology Unit, University of Dar es Salaam, Dar es Salaam, P.O. Box 35050, Tanzania \\ e Museo Arqueológico Regional, Plaza de las Bernardas s/n, 28801 Alcalá de Henares, Madrid, Spain \\ ${ }^{\mathrm{f}}$ Department of Anthropology, University of Wisconsin-Madison, Madison, Wisconsin, 53706, USA \\ ${ }^{g}$ Institute for Human Evolution, University of the Witwatersrand, Private Bag 3, WITS 2050, Johannesburg, South Africa
}

Due to a typesetter error in the final online and print versions of this article, the affiliations of the first Guest Editor, M. Domínguez-Rodrigo, were listed incorrectly. The affiliation shown as the "Department of Anthropology, University of Wisconsin-Madison, Madison, Wisconsin, 53706, USA" was incorrect. His correct affiliations are IDEA (Instituto de Evolución en África), Museo de los Orígenes, Plaza de San Andrés 2, 28005 Madrid, Spain and Department of Prehistory, Complutense University, Prof. Aranguren s/n, 28040 Madrid, Spain.

The complete correct Guest Editors and affiliations are shown here. The publisher apologizes for the error. 